\title{
Does financial integration affect real exchange rate volatility and cross-country equity market returns correlation?
}

\author{
Michael Donadelli ${ }^{\mathrm{a}, *}$, Antonio Paradiso ${ }^{\mathrm{b}}$ \\ a Center of Excellence SAFE, House of Finance, Goethe University Frankfurt, Germany \\ b Department of Economics, Ca' Foscari University of Venice, Italy
}

\section{A R T I C L E I N F O}

\section{Article history:}

Received 16 October 2013

Received in revised form 6 March 2014

Accepted 10 March 2014

\section{Keywords:}

Financial integration

Risk-sharing

Cross-country equity returns correlation

Real exchange rate volatility

\begin{abstract}
A B S T R A C T
Existing empirical studies show that financial integration affects the behavior of average excess returns, cross-country equity market returns (EMR) correlations and real exchange rate (RER) volatility. We employ a recently developed two-country model with recursive preferences, frictionless and complete markets and highly correlated long-run innovations to examine whether full financial integration (i.e. full risk-sharing) affects the US-Canada EMR correlation and the US RER volatility, consistently with existing empirical findings. First, full risk-sharing gives rise to a relatively high RER volatility. Second, it induces very strong positive cross-country EMR correlations. Both quantities are higher than those observed in the US-Canada asset pricing data, and increase as the risk-sharing incentive increases. In contrast, "international consumption quantities" are weakly sensitive to changes in the level of aversion to consumption and utility risk.
\end{abstract}

(C) 2014 Elsevier Inc. All rights reserved.

\section{Introduction}

During the last the last three decades international equity markets have become increasingly integrated. Recent studies show that the level of segmentation across developed equity markets is

\footnotetext{
* Corresponding author. Tel.: +49 6979833882.

E-mail addresses: michael.donadelli@gmail.com (M. Donadelli), antonio.paradiso@unive.it (A. Paradiso).
} 
rather low, that is, equity markets across industrialized economies are close to be fully integrated (Bekaert, Harvey, Lundblad, \& Siegel, 2011; Donadelli, 2013; Pukthuanthong \& Roll, 2009; among others). This facilitates consumption smoothing and risk-sharing opportunities (Jappelli \& Pistaferri, 2011; Kollmann, 2012; Suzuki, 2014). Global financial integration, both de jure and de facto, has received an enormous amount of attention in the international empirical finance literature, much of it devoted to examine its effects on cross-country EMR correlations as well as on RER volatility dynamics and average equity market returns. A large number of empirical studies confirm that the cross-country EMR correlation increases as the level of segmentation across international capital markets decreases (Dellas \& Hess, 2005; Donadelli, 2013; Donadelli \& Persha, 2014; Goetzmann, Li, \& Rouwenhorst, 2005; Longin \& Solnik, 1995). Other studies have shown that a high level of financial integration is an important source of RER volatility (Caporale, Amor, \& Rault, 2011; Corden, 2002; Reinhart \& Todd Smith, 2001). However, there is little research examining the "financial integration-RER volatility and EMR correlation relationships" in a general equilibrium context. This is due to the fact that in most of the recently developed international business cycle models markets are internationally incomplete (e.g."financial autarky", "one-bond world") or display imperfections/frictions (e.g., borrowing constraints, limited asset market participation, enforcement constraints). Why? Standard international business cycle (IBC) models with complete and frictionless markets tend to have problems in matching international macroeconomic data (Backus, Kehoe, \& Kydland, 1994, 1995; Benigno \& Kucuk-Tuger, 2012; Bodenstein, 2008; Heathcote \& Perri, 2002; Kollmann, 2012; Mandelman, Rabanal, Rubio-Ramìrez, \& Vilàn, 2011). In particular, these models, in contrast to empirical evidence, tend to produce a close to unity cross-country consumption correlation, a relatively low equity risk premium (ERP), a relatively low RER volatility and a positive correlation between consumption differentials and real exchange rate. Therefore, past attempts to solve some of these anomalies have focused mostly on models in which only a restricted set of assets can be traded internationally or agents are borrowing constrained. But, in this environment consumption risk-sharing is limited both internationally and domestically (Crucini, 1999; Santos Monteiro, 2008). In reality, there exists a wide array of assets that can be traded (e.g. equities, bonds with different maturities, plain vanilla derivatives, exotic financial products), both domestically and internationally (Kollmann, 2012). Therefore, international equity markets are not segmented, and the intensive trading activity should produce more pressure on the currency market as well as a higher degree of co-movement between international EMR. A partial risk-sharing environment becomes a much more unrealistic assumption if two economies are really close in terms of trade and financial transactions (Tavares, 2009). As estimated by Fitzgerald (2012), the level of financial risk-sharing across developed markets is nearly optimal.

We employ a recently developed two country-two good model with recursive preferences, highly correlated long-run growth innovations, frictionless and complete markets to address whether financial integration affects the RER volatility and the cross-country EMR correlation, an aspect neglected in existing studies. We address this issue by assuming that (i) goods markets are partially integrated; (ii) home and foreign long-run innovations are highly correlated. ${ }^{1}$ In addition, we study the effects of changes in agents' aversion to consumption and utility risk on the RER volatility and cross-country EMR correlation. Our analysis focuses on "US-Canada data". Therefore, we rely on two economies that enjoy one of the closest relationships in the world (consistent with our international capital markets structure). Data run from 1975 to 2007, a period of increasing economic and financial integration. ${ }^{2}$ In particular, over the past three decades, Canada's economic ties to the US have deepened, first under the Free Trade Agreement (FTA) and later under the North American Free Trade Agreement (NAFTA).

We summarize our results as follows. First, and most importantly, full international risk-sharing produces: (i) a relatively high RER volatility and (ii) a strong positive cross-country EMR correlation. We stress that both quantities increase as the level of aversion to utility risk increases (i.e., as the intertemporal elasticity of substitution (IES) increases), and are higher than those observed in the US-Canada data. Second, and not surprisingly, the RER volatility is increasing also in the level of relative risk aversion (RRA). Third, the model produces a relatively low consumption growth volatility

\footnotetext{
1 See also Colacito and Croce (2010).

2 We exclude the sub-prime crisis period because it is characterized by a high number of uncertainty shocks (Bloom, 2009; Cazzavillan \& Donadelli, 2010).
} 

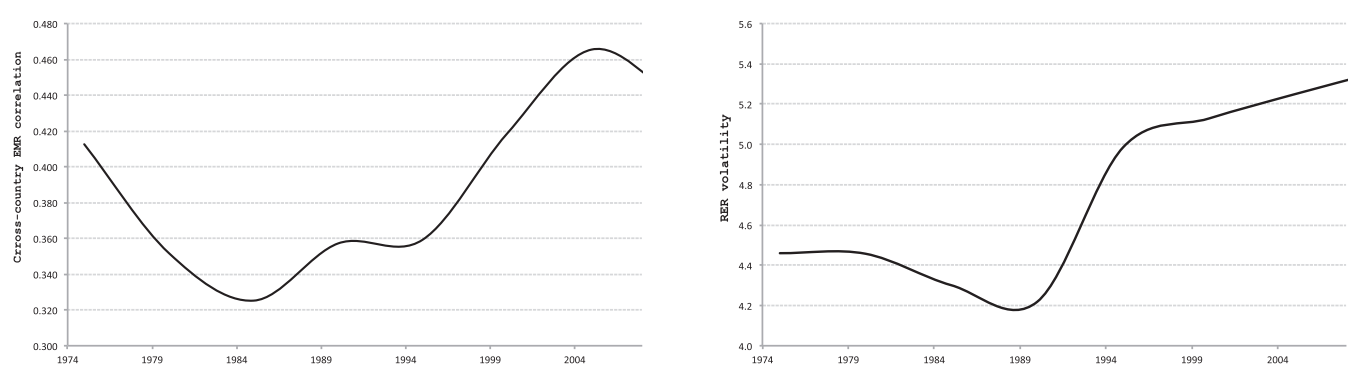

Fig. 1. Cross-country EMR correlation and RER volatility. Notes: This figure reports dynamics of the correlation between US and Canada equity market returns (left panel) and real exchange rate volatility (right panel). Both moments are estimated using a rolling sample of 25 years. Data are annual and run from 1975 to 2007. All details on data sources are reported in Appendix A.

and cross-country consumption correlation, a relatively low risk-free rate, and relatively high ERP (consistent with US-Canada consumption and asset pricing data). Last, the model accounts for the negative correlation between the RER and consumption growth rate differentials (Colacito \& Croce, 2013), regardless of the value of the IES. In contrast, a moderate level of RRA is needed to produce such negative correlation. Overall, we find that changes in the RRA and IES parameters affect mainly the ERP, the risk-free rate and the RER volatility.

The rest of the paper is organized as follows. Section 2 briefly discusses the US-Canada relationship. Section 3 reviews the model. Section 4 presents and discusses the quantitative results of the model. Section 5 concludes.

\section{On the US-Canada relationship}

Both the US and Canada are affluent industrialized economies with similar standards of living and industrial structure. These two economies are characterized by a strong bilateral trade relationship. The total merchandise trade (exports and imports) exceeds $\$ 429.7$ billion in 2009 (Ferguson, 2011). During the last decades these two economies have become increasingly integrated. The integration process has been mainly generated and then strengthened by trade agreements (Courchene, 2003; Poulson, 1990). We refer to the US-Canada free-trade agreement (FTA, signed in 1988) and the North America free-trade agreement (NAFTA, signed in 1994). However, an increasing bilateral trade volume does not represent the only source of integration. On the one side, there has been an enormous amount of foreign direct investment (FDI) during the 1990s (Hufbauer, 2001; Rugman, 2000). On the other side, the equity markets of the two economies tend to follow a similar path, suggesting an increasing degree of financial integration. For example, Johnson and Soenen (2003) find a statistically high percentage of contemporaneous association between the US and Canada stock markets co-movements. Tavares (2009) sustains that the higher degree of co-movement between stock returns is related to a higher bilateral trade intensity. Donadelli (2013) obtains a similar result. We argue that the increasing economic and financial integration process translates into high cross-country EMR correlation and high RER volatility. Fig. 1 reports the dynamics of the RER volatility and cross-country EMR correlation for US-Canada. The empirical evidence confirms that both the RER volatility and the cross-country EMR correlation sharply increased in periods of increasing integration (i.e. after the FTA, as suggested by Lahrech \& Sylwester, 2013). ${ }^{3}$

A large amount of empirical work focuses on the impact of financial integration on asset prices and EMR co-movements (Caporale et al., 2011; Corden, 2002; Dellas \& Hess, 2005; Donadelli, 2013; Goetzmann et al., 2005; Longin \& Solnik, 1995; Reinhart \& Todd Smith, 2001), but few studies examine such relationships in a general equilibrium context. The ultimate goal of this paper is to fill this gap.

\footnotetext{
${ }^{3}$ For a detailed analysis on the dynamics of the financial integration process across advanced and emerging markets, see Pukthuanthong and Roll (2009), and Donadelli (2013).
} 


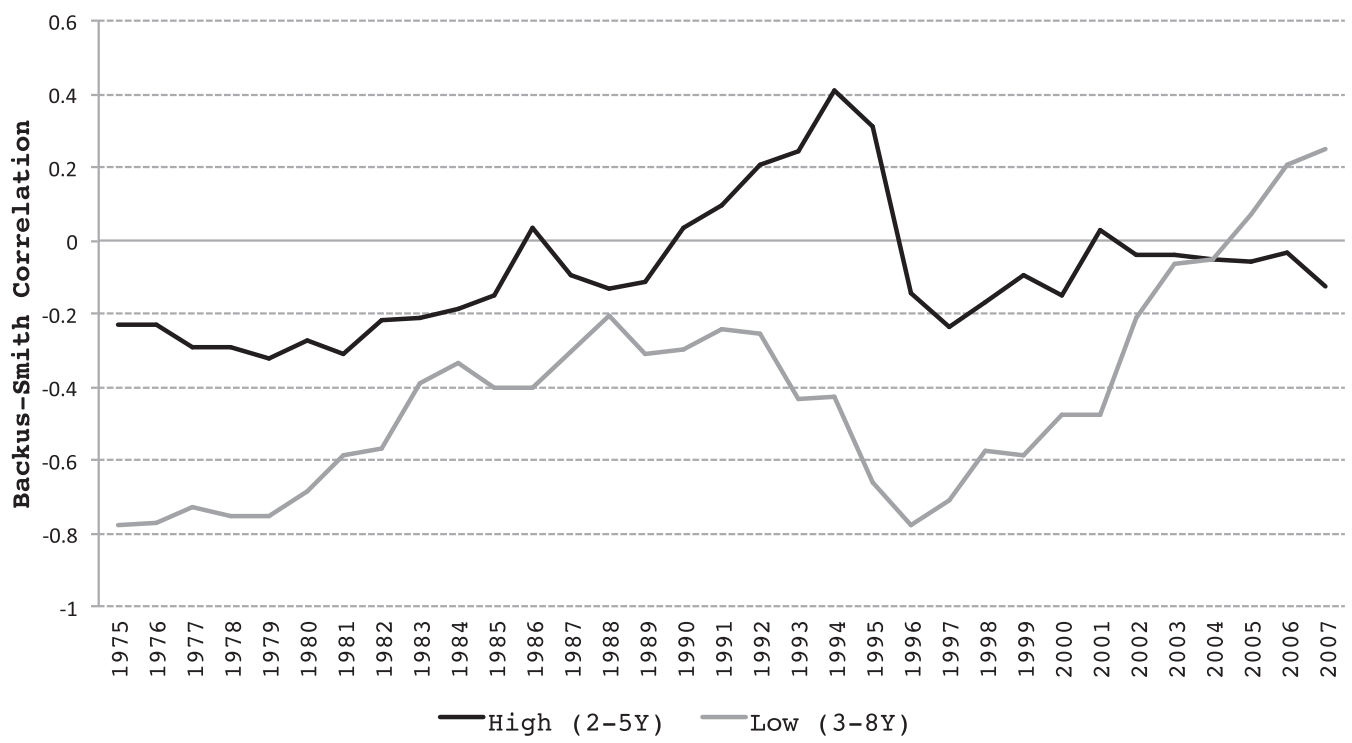

Fig. 2. Consumption-real exchange rate correlation. Notes: This figure reports the dynamics of the consumption-real exchange rate correlation (i.e., Backus-Smith correlation). In the spirit of Corsetti et al. (2012), we decompose the Backus-Smith correlation in its dynamic components at different frequencies. Low frequency (gray line): 3-8 years; high frequency (black line): 2-5 years. In particular, we isolate the cyclical component of the log-levels of relative consumption and real exchange rate using the bandpass filter (Christiano \& Fitzgerald, 2003).

In addition, the most recent IBC literature has mainly focused on the resolution of the Backus and Smith's (1993) anomaly (i.e. the lack in correlation between the real exchange rate and consumption growth differentials) rather than on the RER volatility and cross-country EMR correlation. We stress that most of these studies have been conducted in partial risk-sharing environments (Benigno \& Thoenissen, 2008; Bodenstein, 2008; Corsetti, Dedola, \& Leduc, 2008; Kollmann, 2012, among others). Therefore, we will also examine the Backus-Smith correlation. The US-Canada data for the period 1975-2007 confirm the presence of a negative correlation between the RER and consumption differentials. Over this period, the Backus-Smith correlation is equal to - 0.31. In the spirit of Corsetti, Dedola, and Viani (2012), using the bandpass filter decomposition described in Christiano and Fitzgerald (2003), we re-compute the correlation under different frequency scenarios. Fig. 2 suggests that the Backus-Smith correlation is sensitive to the frequency used to decompose the cycle. In a high frequency cycles (i.e., 2-5 years) context, we find an average correlation of -0.09 . For low frequency cycles (i.e., 3-8 years) the correlation is -0.40 . We stress that, differently from existing IBC models, the model employed in this paper accounts for the negative/low correlation between the RER and the consumption differentials in the US-Canada data even if there is full financial risk-sharing.

\section{The model: a review}

\subsection{Preferences}

The economy is composed by two countries, home $(h)$ and foreign $(f)$, and two goods $G_{h}$ and $G_{f}$. The home (foreign) country is endowed with good $G_{h}\left(G_{f}\right)$. Agents' preferences are defined over a consumption aggregate of good $G_{h}$ and good $G_{f}$. Formally,

$$
C_{h, t}=\left(g_{h, t}^{h}\right)^{\alpha}\left(g_{f, t}^{h}\right)^{1-\alpha} \text { and } C_{f, t}=\left(g_{h, t}^{f}\right)^{1-\alpha}\left(g_{f, t}^{f}\right)^{\alpha}
$$


where $C_{h, t}\left(C_{f, t}\right)$ is the consumption aggregate in the home (foreign) country, $g_{h, t}^{h}\left(g_{h, t}^{f}\right)$ and $g_{f, t}^{h}\left(g_{f, t}^{f}\right)$ denote the consumption of good $G_{h}$ and good $G_{f}$ in the home (foreign) country at time $t$, and $\alpha \in(0,1)$ represents the home bias parameter.

The representative agent in both countries has Epstein and Zin (1989) preferences that takes the following form ${ }^{4}$ :

$$
\begin{aligned}
& U_{h, t}=\left[(1-\delta)\left(C_{h, t}\right)^{1-\gamma / \theta}+\delta E_{t}\left[U_{h, t+1}^{1-\gamma}\right]^{1 / \theta}\right]^{\theta / 1-\gamma} \\
& U_{f, t}=\left[(1-\delta)\left(C_{f, t}\right)^{1-\gamma / \theta}+\delta E_{t}\left[U_{f, t+1}^{1-\gamma}\right]^{1 / \theta}\right]^{\theta / 1-\gamma}
\end{aligned}
$$

where $\delta$ if the subjective discount factor, $\theta=1-\gamma / 1-1 / \psi, \gamma$ is the coefficient of relative risk aversion (RRA), and $\psi$ denotes the intertemporal elasticity of substitution (IES). ${ }^{5}$ Notice that this preference specification allows to separate the RRA parameter from the IES, a key feature for the model to be able to address asset pricing anomalies (Croce, 2008; Pancrazi, 2013). In addition, in this setting agents are risk averse in future utility as well as future consumption. In the special case $\gamma=1 / \psi$ (i.e., $\theta=1$ ), the above specification reduces to the familiar time separable power utility model with period utility $U\left(C_{t}\right)=C_{t}^{1-\gamma} /(1-\gamma)$. In other words, when $\gamma=1 / \psi$, the agent is utility-risk neutral.

\subsection{Endowments}

Endowments are represented by co-integrated process. In addition, we also allow for the presence of predictive variables. Formally,

$$
\begin{aligned}
& \Delta \log G_{h, t}=\mu+z_{h, t-1}+\tau\left(\log G_{f, t-1}-\log G_{h, t-1}\right)+\epsilon_{h, t}^{S R} \\
& \Delta \log G_{f, t}=\mu+z_{f, t-1}+\tau\left(\log G_{h, t-1}-\log G_{f, t-1}\right)+\epsilon_{f, t}^{S R} \\
& z_{h, t}=\rho z_{h, t-1}+\epsilon_{h, t}^{L R} \\
& z_{f, t}=\rho z_{f, t-1}+\epsilon_{f, t}^{L R} .
\end{aligned}
$$

where $\mu$ is the long-run endowment growth rate average, $\tau$ is the co-integration parameter, $z_{h, t}$ and $z_{f, t}$ are highly persistent $\operatorname{AR}(1)$ processes, $\epsilon_{h, t}^{S R}$ and $\epsilon_{f, t}^{S R}$ are short-run shocks, and $\epsilon_{h, t}^{L R}$ and $\epsilon_{f, t}^{L R}$ are long-run shocks. Shocks are distributed as follows

$$
\underbrace{\left(\begin{array}{c}
\epsilon_{h, t}^{S R} \\
\epsilon_{f, t}^{S R} \\
\epsilon_{h, t}^{L R} \\
\epsilon_{f, t}^{L R}
\end{array}\right)}_{\Xi} \sim \text { i.i.d.N }(\underbrace{\left(\begin{array}{l}
0 \\
0 \\
0 \\
0
\end{array}\right)}_{\mathbf{0}}, \underbrace{\left(\begin{array}{cccc}
\sigma_{\epsilon_{h}^{S R}}^{2} & \sigma_{\epsilon_{h}^{S R}, \epsilon_{f}^{S R}} & 0 & 0 \\
\sigma_{\epsilon_{f}^{S R}, \epsilon_{h}^{S R}} & \sigma_{\epsilon_{f}^{2}}^{2} & 0 & 0 \\
0 & 0 & \sigma_{\epsilon_{h}^{L R}}^{2} & \sigma_{\epsilon_{h}^{L R}, \epsilon_{f}^{L R}} \\
0 & 0 & \sigma_{\epsilon_{f}^{L R}, \epsilon_{h}^{L R}} & \sigma_{\epsilon_{f}^{L R}}^{2}
\end{array}\right)}_{\Omega})
$$

where $\Xi$ is the shock vector and $\Omega$ is the variance-covariance matrix of the cross-country short-and long-run shocks.

\footnotetext{
${ }^{4}$ See also Bansal and Yaron (2004) and Pancrazi (2013), among others.

${ }^{5}$ Note that the sign of $\theta$ is determined by the magnitudes of the RRA and the IES. In particular, if $\gamma$ and $\psi$ are both larger than one, then $\theta$ is negative. By substituting $\theta$ in (2a) and (2b), we obtain

$$
U_{i, t}=\left[(1-\delta) C_{i, t}^{1-1 / \psi}+\delta E_{t}\left[U_{i, t+1}^{1-\gamma}\right]^{1-1 / \psi / 1-\gamma}\right]^{1 / 1-1 / \psi}
$$
}

where $i=[h, f]$, and $\gamma>1 / \psi$ introduces preferences for early resolution of uncertainty. 


\subsection{International complete markets}

Frictionless international capital markets imply the following home and foreign budget constraints:

$$
\begin{aligned}
& g_{h, t}^{h}+p_{t} g_{f, t}^{h}+\sum_{s_{t+1}} P_{t+1}\left(s^{t+1}\right) A_{h, t+1}\left(s^{t+1}\right) \leq G_{h, t}+A_{h, t} \\
& g_{h, t}^{f}+p_{t} g_{f, t}^{f}+\sum_{s_{t+1}} P_{t+1}\left(s^{t+1}\right) A_{f, t+1}\left(s^{t+1}\right) \leq p_{t} G_{f, t}+A_{f, t}
\end{aligned}
$$

where $p_{t}$ is the price of good Y in terms of good X, $A_{h, t}\left(s^{t}\right)\left(A_{f, t}\left(s^{t}\right)\right)$ is the home (foreign) claim to time $t$ consumption of good $G_{h}\left(G_{f}\right)$, and $P_{t+1}$ is the state-contingent price. ${ }^{6}$

\subsection{Allocations}

In this setting, the Pareto optimal allocation takes the following form ${ }^{7}$

$$
\begin{aligned}
& g_{h, t}^{h}=\alpha G_{h, t}\left[1+\frac{(1-\alpha)\left(S_{t}-1\right)}{1-\alpha+\alpha S_{t}}\right], \quad g_{h, t}^{f}=(1-\alpha) G_{h, t}\left[1+\frac{\alpha\left(S_{t}-1\right)}{1-\alpha+\alpha S_{t}}\right] \\
& g_{f, t}^{h}=(1-\alpha) G_{f, t}\left[1+\frac{\alpha\left(S_{t}-1\right)}{\alpha+(1-\alpha) S_{t}}\right], \quad g_{f, t}^{f}=\alpha G_{f, t}\left[1+\frac{(1-\alpha)\left(S_{t}-1\right)}{\alpha+(1-\alpha) S_{t}}\right]
\end{aligned}
$$

where

$$
S_{t}=S_{t-1} \frac{M_{h, t}}{M_{f, t}}\left(\frac{e^{\Delta c_{h, t}}}{e^{\Delta c_{f, t}}}\right)
$$

and $M_{h, t}\left(M_{f, t}\right)$ is the home (foreign) stochastic discount factor.

\subsection{Stochastic discount factor and RER}

The stochastic discount factor (SDF) in this setting is

$$
M_{i, t+1}=\delta\left(\frac{C_{i, t+1}}{C_{i, t}}\right)^{-(1 / \psi)}\left(\frac{U_{i, t+1}^{1-\gamma}}{E_{t}\left[U_{i, t+1}^{1-\gamma}\right]}\right)^{1 / \psi-\gamma / 1-\gamma}
$$

where $i=[h, f]$. In the special case $1 / \psi=\gamma$, (7) collapses to the standard SDF $M_{t+1}=\delta\left(C_{t+1} / C_{t}\right)^{-\gamma}$.

Under market completeness the RER takes the following form:

$$
\Delta r x=\log M_{f, t}-\log M_{h, t}
$$

\section{Benchmark calibration}

The long-run growth rate of endowment $(\mu)$, the persistence of the long-run risk component $(\rho)$, the RRA and the IES parameters are defined as in previous studies (Bansal \& Yaron, 2004; Colacito \& Croce, 2010; Pancrazi, 2013). The level of IES ensures that equity prices rise with expected future consumption growth and fall with volatility of consumption growth, while the level of RRA delivers high ERP. Because RRA is greater than the reciprocal of IES, the ERP is driven not only by covariances of equity returns with current consumption, as in the classic power-utility model of Mehra and Prescott (1985), but also by the covariances of equity returns with expected future consumption growth (Restoy \& Weil, 2011). As in Colacito and Croce (2010), we set $\alpha=0.97$ (i.e., preference home bias towards domestic goods). This implies a high degree of goods market segmentation (see Bacchetta $\&$ van Wincoop, 2013). $\tau, \sigma_{\epsilon R}$,

${ }^{6}$ In equilibrium, $A_{h, t}+A_{f, t}=0, \forall t$

7 Details on the social planner's problem can be found in Colacito and Croce (2013). 
Table 1

Benchmark calibration.

\begin{tabular}{lll}
\hline Parameter & & Value \\
\hline$\mu$ & Endowment long-run growth rate & $2.00 \%$ \\
$\alpha$ & Consumption home-bias & 0.97 \\
$\tau$ & Co-integration parameter & $0.05 \%$ \\
$\delta$ & Subjective discount factor & 0.98 \\
$\gamma$ & Relative risk aversion (RRA) & 8 \\
$\psi$ & Intertemporal elasticity of substitution (IES) & 1.5 \\
$\sigma_{\epsilon L R}$ & Long-run shock volatility & $4 \% *\left(\sigma_{\epsilon} S R\right)$ \\
$\sigma_{\epsilon S R}$ & Short-run shock volatility & $1.87 \%$ \\
$\rho$ & Long-run component persistence & 0.985 \\
$\rho_{\epsilon_{h}^{L R} \epsilon_{f}^{L R}}$ & Long-run shocks correlation & 0.90 \\
$\rho_{\epsilon_{h}^{S R} \epsilon_{f}^{S R}}$ & Short-run shocks correlation & 0.05 \\
\hline
\end{tabular}

Table 2

Matching international consumption data: The role of IES. Notes: This table reports real consumption growth rate volatility, $\sigma(\Delta c)$; cross-country consumption growth correlation, $\operatorname{Corr}\left(\Delta c_{h}, \Delta c_{f}\right)$; and the US-Canada Backus-Smith correlation, $\operatorname{Corr}\left(\Delta c_{h}-\Delta c_{f}, \Delta r x\right)$. All parameters are calibrated to the values reported in Table 1 . Moments are calculated as the average over 100 simulations of 100 periods. ${ }^{*}-0.09$ is the average high-frequency Backus-Smith correlation and -0.40 is the average low-frequency Backus-Smith correlation. Data are annual and run from 1975 to 2007. All details on data sources are reported in Appendix A.

\begin{tabular}{lcccccc}
\hline Model (with LRR) & $(1)$ & $(2)$ & $(3)$ & $(4)$ & \multicolumn{1}{l}{ (5) } & Data \\
& $\psi=0.9$ & $\psi=1.1$ & $\psi=1.3$ & $\psi=1.5$ & $\psi=2$ & \\
\hline$\sigma(\Delta c)$ & 2.16 & 2.17 & 2.16 & 2.13 & 2.11 & 1.52 \\
$\operatorname{Corr}\left(\Delta c_{h}, \Delta c_{f}\right)$ & 0.52 & 0.51 & 0.53 & 0.58 & 0.63 & 0.63 \\
$\operatorname{Corr}\left(\Delta c_{h}-\Delta c_{f}, \Delta r x\right)$ & -0.19 & -0.21 & -0.18 & -0.14 & -0.30 & $-0.31[-0.09,-0.40]^{*}$ \\
\hline
\end{tabular}

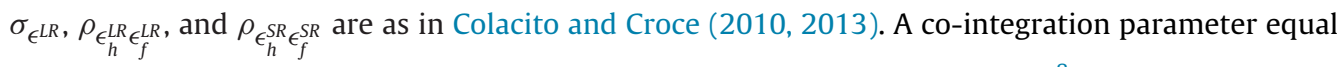
to 0.0005 implies a very slow cross-country endowments adjustment (Table 1 ). ${ }^{8}$

\section{Quantitative results}

Recent IBC studies have mainly focused on the resolution of the consumption-RER anomaly and are silent on the RER volatility and cross-country EMR correlation as well as on asset prices. In this section, we focus on the following quantities and prices: average ERP, $E\left(R_{e, h}-R^{f}\right)$; average risk-free rate, $E\left(R^{f}\right)$; risk-free rate volatility, $\sigma\left(R^{f}\right)$; cross-country equity market returns correlation, $\operatorname{Corr}\left(R_{e, h}, R_{e f}\right)$; consumption growth volatility, $\sigma(\Delta c)$; cross-country consumption growth correlation, $\operatorname{Corr}\left(\Delta c_{h}, \Delta c_{f}\right)$; real exchange rate volatility, $\sigma(\Delta r x)$; and Backus and Smith's (1993) correlation, $\operatorname{Corr}\left(\Delta c_{h}-\Delta c_{f}, \Delta r x\right)$. Then, we examine whether a full international risk sharing environment (i.e. full financial integration) is responsible for the relatively high RER volatility and the positive cross-country EMR correlation observed in the US-Canada data.

\subsection{International consumption data}

Consumption volatility, cross-country consumption growth correlation and consumption differentials-RER correlation produced by the model are reported in Tables 2 and 3 . Entries in Tables 2 and 3 are obtained by assuming different IES and RRA values, respectively. In line with existing studies in the long-run risk literature, we let $\psi$ ranging from a value lower than 1 to 2 . As suggested by Mehra and Prescott (2008), we assume that $\gamma \in[4,10]$. The last column in both tables reports US-Canada empirical moments.

${ }^{8}$ Note that this is consistent with empirical findings. 


\section{Table 3}

Matching international consumption data: the role of RRA. Notes: This table reports real consumption growth rate volatility, $\sigma(\Delta c)$; cross-country consumption growth correlation, $\operatorname{Corr}\left(\Delta c_{h}, \Delta c_{f}\right)$; and the US-Canada Backus-Smith correlation, $\operatorname{Corr}\left(\Delta c_{h}-\Delta c_{f}, \Delta r x\right)$. All parameters are calibrated to the values reported in Table 1. Moments are calculated as the average over 100 simulations of 100 periods. ${ }^{*}-0.09$ is the average high-frequency Backus-Smith correlation and -0.40 is the average low-frequency Backus-Smith correlation. Data are annual and run from 1975 to 2007. All details on data sources are reported in Appendix A.

\begin{tabular}{lllccl}
\hline Model (with LRR) & $(1)$ & $(2)$ & $(3)$ & $(4)$ & Data \\
& $\gamma=4$ & $\gamma=6$ & $\gamma=8$ & $\gamma=10$ & \\
\hline$\sigma(\Delta c)$ & 2.12 & 2.11 & 2.13 & 2.20 & 1.52 \\
$\operatorname{Corr}\left(\Delta c_{h}, \Delta c_{f}\right)$ & 0.53 & 0.57 & 0.58 & 0.51 & 0.63 \\
$\operatorname{Corr}\left(\Delta c_{h}-\Delta c_{f}, \Delta r x\right)$ & 0.26 & 0.08 & -0.14 & -0.21 & $-0.31[-0.09,-0.40]^{*}$ \\
\hline
\end{tabular}

Based on these entries, we can draw the following conclusions. First, our full risk sharing environment produces a relatively low cross-country consumption growth correlation (consistent with US-Canada consumption data), regardless of the level of aversion to risk. In other words, the consumption correlation is much lower than one even if there are changes in the $\psi$ and $\gamma$ parameters. We argue that this result is mainly driven by the presence of a high level goods markets segmentation (i.e., $\alpha=0.97$ ). ${ }^{9}$ The result is in stark contrast to the findings presented in previous IBC studies with complete financial markets (see Bodenstein, 2008; Heathcote \& Perri, 2002; Devereux \& Yetman, 2010). In fact, standard IBC models with complete markets tend to produce a close to unity crosscountry consumption correlation (i.e. a high level of risk sharing tends to produce a strong positive cross-country consumption correlation). ${ }^{10}$ In order to address this international macroeconomic puzzle most studies include either financial market imperfections or partial risk sharing (Bodenstein, 2008; Heathcote \& Perri, 2002, among many others). However, recent estimates show that the level of financial risk sharing across developed markets is very high (Bekaert et al., 2011; Fitzgerald, 2012). In contrast, trade market frictions are still sizable (Bacchetta \& van Wincoop, 2013; Ready, Roussanov, \& Wards, 2013). Early evidence on the level of segmentation of international goods markets can be found in McCallum (1995). The author observes that trade among Canadian provinces is twenty times greater than between Canadian provinces and US states. Tretvoll (2008) argues that there is strong home-bias in consumption. However, due to the enormous growth in US-Canada trade since 1990, the consumption home bias parameter should be lower than 0.97. For example, Bacchetta and van Wincoop (2013) show that $\alpha=0.88$ is sufficient to guarantee a global panic. In his benchmark calibration, Tretvoll (2008) imposes $\alpha=0.85$. As robustness check, we have re-simulated the model by imposing more realistic values for the consumption home bias parameter (i.e., $\alpha=0.90,0.85$ ). Results are reported in Table B.1 (see specifications (5) and (6)). We show that the model produces a relatively low consumption growth correlation even if there is a higher level of economic integration.

Second, we find that the model accounts for the negative correlation between the RER and the consumption growth rate differentials in the data. Note that the model's success in solving the Backus-Smith anomaly is not affected by changes in the IES parameter. On the contrary, a moderate amount of risk aversion (i.e., $\gamma>6$ ) is needed to address this international macroeconomic anomaly. How does the model generate the Backus-Smith correlation? In presence of positive short-run news to the supply of the domestic good, the marginal utility of consumption at home decreases. This induces the home country to export part of its extra amount of good $G_{h}$. However, preferences towards domestic goods allow the foreign country to take only a small amount of $G_{h}$. Therefore, consumption will increase in both countries, but relatively more at home. Because of the excess supply of $G_{h}$, the domestic currency depreciates. It turns out that both the consumption differentials and the RER volatility increase (i.e., $\operatorname{corr}\left(\Delta c_{h}-\Delta c_{f}, \Delta r x>0\right)$. This does not address the Backus-Smith anomaly. In contrast, upon the realization of positive long-run news, $\Delta c_{h}-\Delta c_{f}$ and $\Delta r x$ move in opposite directions (see

\footnotetext{
9 See also Bodenstein (2008).

10 Heathcote and Perri (2002) examine an economy with only traded goods for the case of complete markets, exogenously incomplete markets with one non-state-contingent bond and financial autarky. They find a low RER volatility since consumption turns out to be highly correlated across countries.
} 

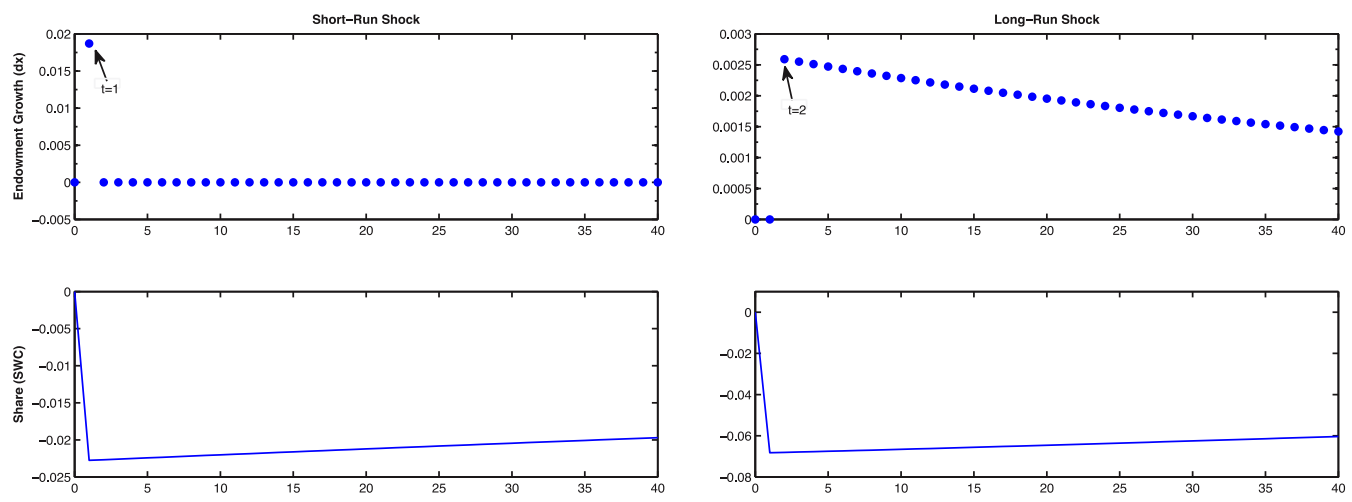

Fig. 3. Trade channel and consumption share (benchmark calibration): positive short- and long-run news to the supply of the home good. This figure presents the impulse response function of domestic country consumption share (bottom panel), and short-(top-left panel) and long-run (top-right panel) endowment shocks dynamics.

Fig. B.1). As shown in Fig. 3, long-run news affects only the future supply of the domestic goods (i.e., from $t=2$ onward). As pointed out in Colacito and Croce (2013), this heavily affects the lifetime utility value. A rise in continuation utility - produced by positive long-run news - gives rise to a decline in marginal utility. Therefore, as in the case of a short-run shock, it is optimal to reduce domestic consumption. In other words, resources tend to flow from the domestic country (i.e hit by relatively good news) to the foreign country (i.e. hit by relatively bad news). This implies a negative consumption growth differential (i.e. $\Delta c_{h} \downarrow$ and $\Delta c_{f} \uparrow \Rightarrow \Delta c_{h}-\Delta c_{f}<0$ ), which jointly with a depreciation of the home currency (i.e. $\Delta(r x) \uparrow)$, produces the Backus-Smith correlation. This is clear from Fig. B.1, which plots the impulse responses of the endowment growth rate, the RER growth rate, the consumption growth rate and the equity return to long-run shocks. We stress that this mechanism becomes stronger as agents become more risk averse in future utility as well as future consumption. In other words, a higher $\psi$ and $\gamma$ produce a higher (negative) consumption differentials-RER correlation.

Along with the results obtained by assuming a lower level of economic integration, Table B.1 reports prices and quantities simulated by the model for different values of the cointegration parameter $\tau$ (specifications (1)-(4) in Table B.1) and for a lower level of co-movement between long-run shocks (specification (7) in Table B.1). We observe the following: (i) model's success in mimicking US-Canada consumption data is weakly affected by changes in $\tau, \alpha$ and $\rho_{\epsilon_{h}^{S R}} \epsilon_{f}^{S R}$; (ii) $\tau<1 \%$ is needed to account for the negative correlation between the RER and the consumption growth differentials in the US-Canada data.

\subsection{Asset pricing data}

Tables 4 and 5 report financial prices and quantities produced by the model for different IES and RRE values, respectively. Entries in both tables suggest that market completeness (i.e. full

\section{Table 4}

Matching asset pricing data: the role of $\psi$. Notes: This table reports the ERP, $E\left(R_{e, h}-R^{f}\right)$; average risk-free rate, $E\left(R^{f}\right)$; risk-free rate volatility, $\sigma\left(R^{f}\right)$; cross-country EMR correlation, $\operatorname{Corr}\left(R_{e, h}, R_{e, f}\right)$; RER volatility, $\sigma(\Delta r x)$. All parameters are calibrated to the values reported in Table 1. Moments are calculated as the average over 100 simulations of 100 periods. Data are annual and run from 1975 to 2007. All details on data sources are reported in Appendix A.

\begin{tabular}{lcccccc}
\hline Model (with LRR) & $(1)$ & $(2)$ & $(3)$ & $(4)$ & (5) & Data \\
& $\psi=0.9$ & $\psi=1.1$ & $\psi=1.3$ & $\psi=1.5$ & $\psi=2$ & \\
\hline$E\left(R_{e, h}-R^{f}\right)$ & -0.22 & 0.62 & 1.53 & 2.47 & 4.76 & 3.78 \\
$E\left(R^{f}\right)$ & 3.90 & 3.12 & 2.41 & 1.75 & 0.27 & 1.52 \\
$\sigma\left(R^{f}\right)$ & 1.36 & 1.15 & 0.94 & 0.76 & 0.39 & 2.28 \\
Corr $\left(R_{e, h}, R_{e, f}\right)$ & 0.36 & 0.44 & 0.68 & 0.78 & 0.90 & 0.43 \\
$\sigma(\Delta r x)$ & 15.14 & 15.60 & 15.80 & 16.21 & 20.05 & 5.13 \\
\hline
\end{tabular}




\section{Table 5}

Matching asset pricing data: the role of $\gamma$. Notes: This table reports the equity risk premium, $E\left(R_{e, h}-R^{f}\right)$; average risk-free rate, $E\left(R^{f}\right)$; risk-free rate volatility, $\sigma\left(R^{f}\right)$; cross-country equity returns correlation, $\operatorname{Corr}\left(R_{e, h}, R_{e, f}\right)$; RER volatility, $\sigma(\Delta r x)$. All parameters are calibrated to the values reported in Table 1 . Moments are calculated as the average over 100 simulations of 100 periods. Data are annual and run from 1975 to 2007. All details on data sources are reported in Appendix A.

\begin{tabular}{llcccc}
\hline Model (with LRR) & $(1)$ & $(2)$ & $(3)$ & $(4)$ & Data \\
& $\gamma=4$ & $\gamma=6$ & $\gamma=8$ & $\gamma=10$ & 3.78 \\
$E\left(R_{e, h}-R^{f}\right)$ & 1.10 & 1.79 & 2.47 & 3.15 & 1.41 \\
$E\left(R^{f}\right)$ & 2.43 & 2.09 & 1.75 & 0.73 & 2.28 \\
$\sigma\left(R^{f}\right)$ & 0.80 & 0.78 & 0.76 & 0.76 & 0.43 \\
$\operatorname{Corr}\left(R_{e, h}, R_{f, h}\right)$ & 0.82 & 0.81 & 16.21 & 20.79 & 5.13 \\
$\sigma(\Delta r x)$ & 9.86 & 12.82 & & 0.78 & \\
\hline
\end{tabular}

financial integration) produces a relatively high RER volatility and a strong positive cross-country EMR correlation.

On the one side, we support existing international finance studies showing that a higher level of financial integration (i.e. risk-sharing improvement) increases the cross-country EMR correlation and the RER volatility. On the other side, these two quantities do not perfectly match US-Canada asset pricing data. In particular, under the benchmark calibration, the RER volatility is three times higher than the one found in the data and the cross-country EMR correlation is two times higher than in the data. ${ }^{11}$ Entries in Table 4 also suggest that the RER volatility and the degree of co-movement between EMR are sensitive to changes in the $\psi$ parameter. This is clear from Fig. 4 which reports the cross-country EMR correlation (left panel) and the RER volatility (right panel) against the IES. As the IES increases, agents become more and more averse to utility risk (i.e. $\gamma-1 / \psi$ increases) and are more willing to smooth consumption (through international trade). In other words, a higher IES produces a stronger risk-sharing incentive. In doing so, both the RER volatility and the EMR correlation increase. Similarly, and not surprisingly, the RER volatility is increasing in $\gamma$. Note that $\gamma=4$ and $\gamma=10$, produces a RER volatility equal to $9.86 \%$ and $20.79 \%$, respectively. In contrast, changes in the RRA do not have large effects on the degree of co-movements between equity returns.

In contrast to standard IBC models with complete and frictionless markets as well as power utility, this model accounts for two important asset pricing puzzles, the risk-free rate puzzle (Weil, 1989) and the equity premium puzzle (Mehra \& Prescott, 1985, 2008). With recursive preferences, the ERP depends not only on the contemporaneous consumption growth-stock return covariance, but also on the covariance of stock return with shocks to expected future consumption growth. Therefore, if $\psi>1 / \gamma$ (as assumed in the long-run risks literature) an asset that pays off when there is an upward revision in expected consumption growth is risky and commands a premium. In fact, the model produces a low risk-free rate and a relatively high ERP. In line with the long-run risk literature (Bansal \& Yaron, 2004), we observe that (i) the ERP increases as the IES and RRA increase; (ii) the ERP is negative for $\psi<1$; (iii) the riskless interest rate is high when $\psi<1$.

A comparison between entries in Tables 2 and 3 and entries in Tables 4 and 5 suggests that changes in the $\psi$ and $\gamma$ parameters affects mainly financial quantities and prices. ${ }^{12}$

Based on entries in Table B.1, which reports quantities and prices for different values of $\tau, \alpha$ and $\rho_{\epsilon_{1}^{L R} \epsilon_{2}^{L R}}$, we also observe that (i) a faster adjustment (i.e., $\tau \uparrow$ ) affects only the RER volatility; (ii) the RER volatility decreases as economic integration increases (i.e., $\alpha \downarrow$ ); ${ }^{13}$ (iii) a lower degree of co-movement between long-run shocks produces a lower cross-country EMR correlation and a higher RER volatility (see specification (7) in Table B.1).

\footnotetext{
11 See specification (4) in Table 4.

12 See also Bodenstein (2008).

13 A higher level of economic integration improves risk-sharing via goods markets among countries. This implies that agents can use goods rather than securities in order to smooth consumption. As a results, there will be a drop in the international trading of securities (i.e., a drop in the amount of pressure on currency).
} 


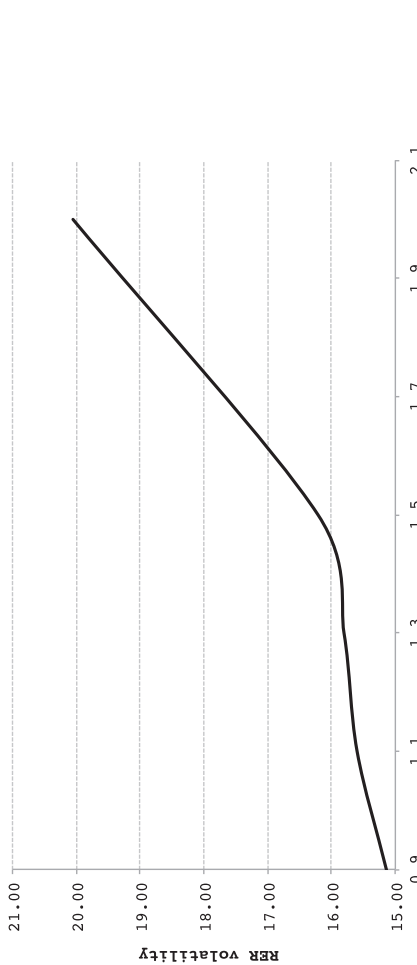

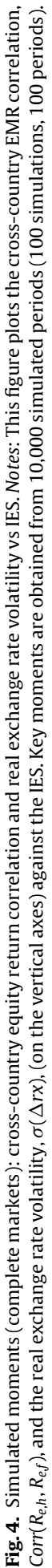

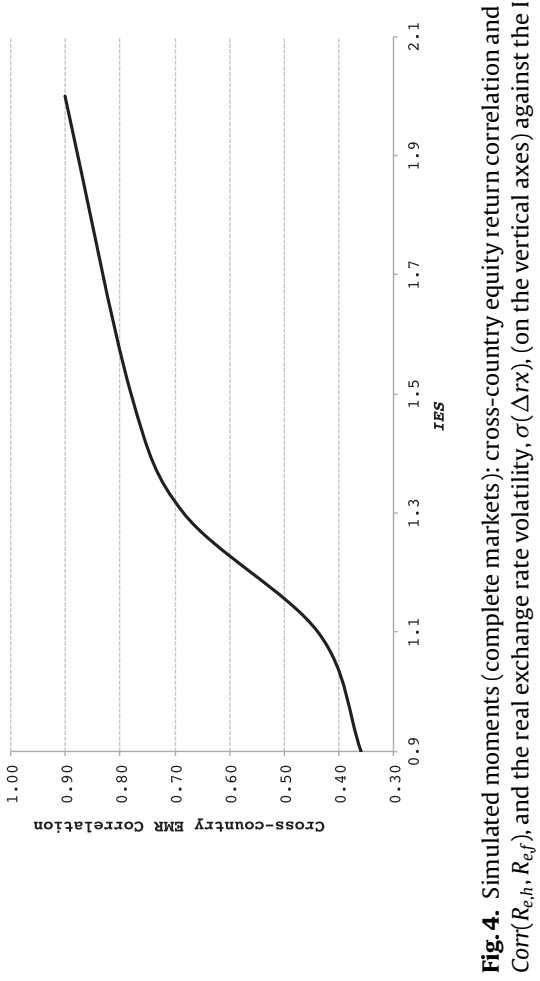

Please cite this article in press as: Donadelli, M., \& Paradiso, A. Does financial integration affect real exchange rate volatility and cross-country equity market returns correlation? North American Journal of Economics and Finance (2014), http://dx.doi.org/10.1016/j.najef.2014.03.001 
Overall, our results confirm existing empirical studies on the impact of financial integration on international quantities and prices by showing that a high level of financial integration (i.e. full risksharing) produces a high RER volatility and a strong positive cross-country EMR correlation.

\section{Concluding remarks}

The increasing level of integration across both the financial and goods markets of the major industrialized economies has largely affected statistical features of real and financial aggregates. It is widely accepted that a high level of integration affects the degree of co-movement between international securities as well as the dynamics of the RER. This paper aims to match these empirical regularities in a general equilibrium context by focusing on US-Canada consumption and asset pricing data over the period 1975-2007. We employ a two country-two good model with recursive preferences, highly correlated long-run innovations and complete markets to examine the impact of full financial integration on the RER volatility and cross-country EMR correlation. In contrast to recent IBC studies that are silent on the asset prices and EMR co-movements, we show that the model produces a higher RER volatility and cross-country EMR correlation than those observed in the US-Canada asset pricing data. This supports existing empirical studies suggesting that markets completeness (i.e. full risk-sharing) allows for a high RER volatility and a strong positive cross-country EMR correlation. We stress that these two quantities increase as the aversion to utility risk increases.

In addition, we show that the model matches pretty well US-Canada consumption data. In particular, it produces a relatively low consumption growth volatility and cross-country consumption correlation, as well as a negative correlation between the RER and consumption differentials (i.e. it solves the Backus-Smith anomaly). In contrast to asset prices, these quantities are weakly sensitive to changes in the IES and RRA parameters.

Overall, this paper establishes a clear theoretical link between financial integration, and the RER volatility and cross-country EMR correlation.

\section{Acknowledgements}

We would like to thank Hamid Beladi (the editor) and an anonymous referee. We are grateful to Monica Billio, Andrea Moro, Muddit Poonia, Alessia Varani and Paolo Vitale for helpful comments and suggestions. We also thank the seminar participants at LUISS Guido Carli, Ca' Foscari University of Venice, Brunel University and Hall Institute for Economic Research. All remaining errors are our own.

\section{Appendix A. Data description}

- Annualized return of a risk-free rate asset: The return of 1-month Treasury bill (1975-2007, Fama and French Data Library);

- Annual return on S\& P 500: Annual average Standard and Poor's Composite Stock Price Index (1975-2007, FED St. Louis);

- Annual return on S\&P/TSX: Annual average S\&P/TSX Composite Stock Price Index (1975-2007, Datastream);

- Prices: Annual US/Canada Average Consumer Price Index (1975-2007, OECD)

- Real consumption: Annual US/Canada Final consumption expenditure of households (1975-2007, $O E C D)$;

- Real consumption: Private Final Consumption Expenditure (1975-2007, FED St. Louis);

- Nominal exchange rate: Annual average Canada / U.S. Foreign Exchange Rate (1975-2007, FED St. Louis);

\section{Appendix B. Additional quantitative results}

See Table B.1.

See Fig. B.1. 


\section{Table B.1}

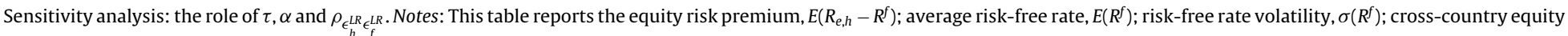

returns correlation, $\operatorname{Corr}\left(R_{e, h}, R_{e f}\right)$; real consumption growth rate volatility, $\sigma(\Delta c)$; cross-country consumption growth correlation, $\operatorname{Corr}\left(\Delta c_{h}, \Delta c_{f}\right)$; real exchange rate volatility, $\sigma(\Delta r x)$; and the Backus-Smith correlation, $\operatorname{Corr}\left(\Delta c_{h}-\Delta c_{f}, \Delta r x\right)$. All parameters are calibrated to the values reported in Table 1. Moments are calculated as the average over 100 simulations of 100 periods. ${ }^{*}-0.09$ is the average high-frequency Backus-Smith correlation and -0.40 is the average low-frequency Backus-Smith correlation. Data are annual and run from 1975 to 2007. All details on data sources are reported in Appendix A.

\begin{tabular}{|c|c|c|c|c|c|c|c|c|}
\hline Model (with LRR) & $\begin{array}{l}(1) \\
\tau=0.1 \%\end{array}$ & $\begin{array}{l}(2) \\
\tau=0.15 \%\end{array}$ & $\begin{array}{l}(3) \\
\tau=0.5 \%\end{array}$ & $\begin{array}{l}(4) \\
\tau=1 \%\end{array}$ & $\begin{array}{l}(5) \\
\alpha=0.9 \downarrow\end{array}$ & $\begin{array}{l}(6) \\
\alpha=0.85 \downarrow\end{array}$ & $\begin{array}{l}\text { (7) } \\
\rho_{\epsilon_{h}^{L R} \epsilon_{f}^{L R}}=0.8 \downarrow\end{array}$ & Data \\
\hline \multicolumn{9}{|l|}{ Asset pricing data } \\
\hline$E\left(R_{e, h}-R^{f}\right)$ & 2.47 & 2.46 & 2.45 & 2.44 & 2.43 & 2.43 & 2.34 & 3.78 \\
\hline$E\left(R^{f}\right)$ & 1.75 & 1.75 & 1.76 & 1.76 & 1.77 & 1.77 & 1.86 & 1.52 \\
\hline$\sigma\left(R^{f}\right)$ & 0.75 & 0.75 & 0.75 & 0.75 & 0.75 & 0.75 & 0.77 & 2.28 \\
\hline $\operatorname{Corr}\left(R_{e, h}, R_{e, f}\right)$ & 0.78 & 0.78 & 0.76 & 0.75 & 0.80 & 0.82 & 0.66 & 0.43 \\
\hline$\sigma(\Delta r x)$ & 16.63 & 16.77 & 14.90 & 11.64 & 6.61 & 3.95 & 22.51 & 5.13 \\
\hline \multicolumn{9}{|l|}{ Int'L Cons. data } \\
\hline$\sigma(\Delta c)$ & 2.13 & 2.12 & 2.11 & 2.10 & 2.17 & 2.10 & 2.70 & 1.52 \\
\hline $\operatorname{Corr}\left(\Delta c_{h}, \Delta c_{f}\right)$ & 0.56 & 0.55 & 0.54 & 0.54 & 0.48 & 0.55 & 0.16 & 0.63 \\
\hline $\operatorname{Corr}\left(\Delta c_{h}-\Delta c_{f}, \Delta r x\right)$ & -0.19 & -0.20 & -0.09 & 0.12 & -0.52 & -0.45 & -0.53 & $-0.31[-0.09,-0.40]^{*}$ \\
\hline
\end{tabular}



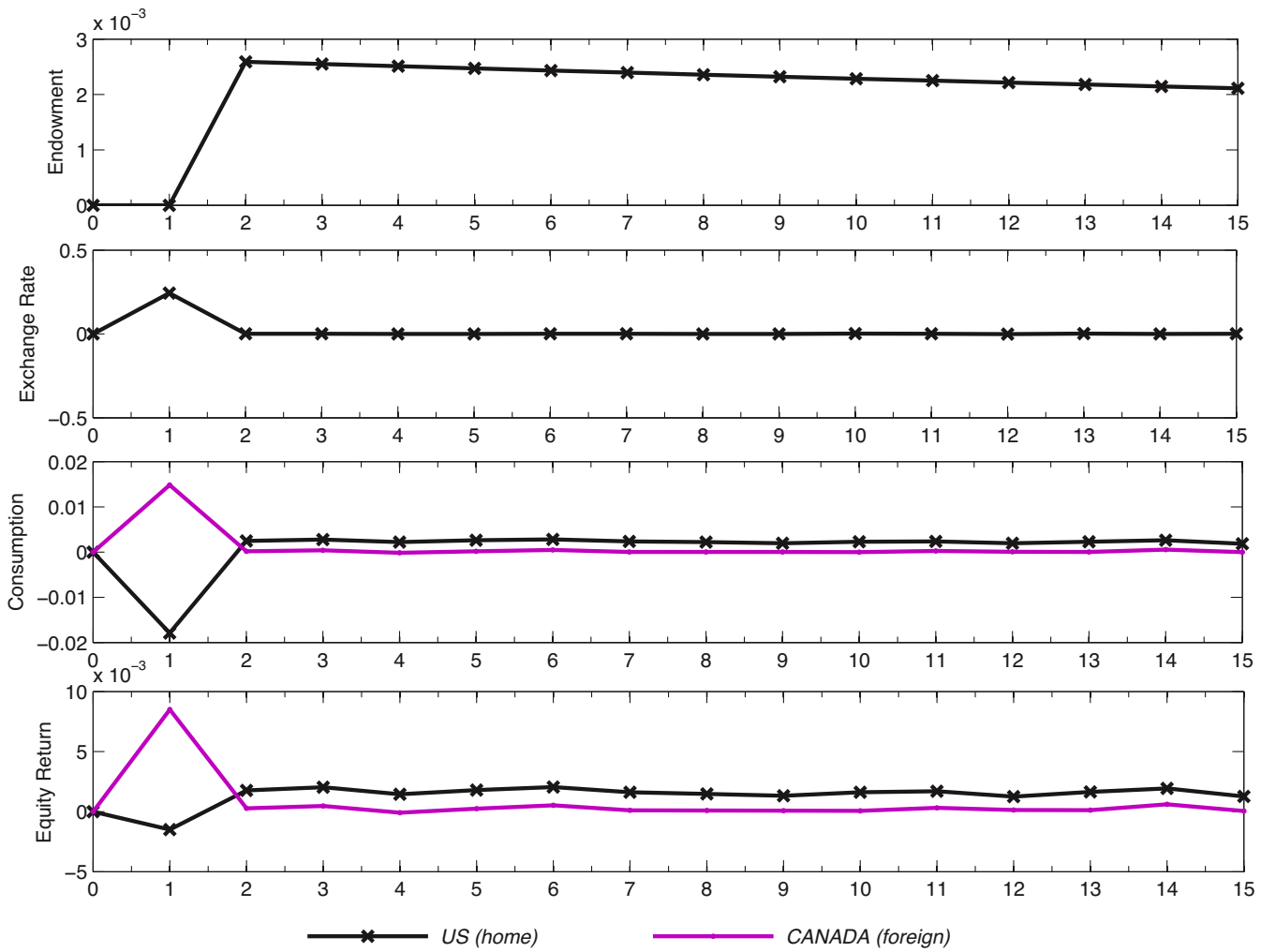

Fig. B.1. The mechanism: Impulse responses to long-run innovations. Notes: This figure shows the impulse response function of endowment $(\Delta G)$, exchange rate $(\Delta r x)$, consumption growth $(\Delta c)$, and equity returns $\left(R_{e}\right)$ for both the home country (black line) and the foreign country (pink line). Annual log deviations from the steady state are reported in the vertical axes. Horizontal axes report years after the shocks. Parameter values are as in Table 1.

\section{References}

Bacchetta, P., \& van Wincoop, E. (2013). The great recession: A self-fulfilling global panic. NBER Working Paper No. 19062.

Backus, D. K., \& Smith, G. (1993). Consumption and real exchange rate in dynamic exchange economies with non traded goods. Journal of International Economics, 35, 297-316.

Backus, D. K., Kehoe, P. J., \& Kydland, F. E. (1994). Dynamics of the trade balance and terms of trade: The J-curve? American Economic Review, 84, 84-103.

Backus, D. K., Kehoe, P. J., \& Kydland, F. E. (1995). International business cycles: Theory and evidence. In T. Cooley (Ed.), Frontiers of business cycles research (pp. 331-356). Princeton University Press.

Bansal, R., \& Yaron, A. (2004). Risks for the long-run: A potential resolution of asset pricing puzzles. Journal of Finance, 59, 1481-1509.

Benigno, G., \& Kucuk-Tuger, H. (2012). Portfolio allocation and international risk sharing. Canadian Journal of Economics, 45(2), $535-565$.

Benigno, G., \& Thoenissen, C. (2008). Consumption and real exchange rates with incomplete markets. Journal of International Money and Finance, 27, 926-948.

Bekaert, G., Harvey, C. R., Lundblad, C., \& Siegel, S. (2011). What segments equity markets? Review of Financial Studies, 24(12), $3841-3890$.

Bloom, N. (2009). The impact of uncertainty shocks. Econometrica, 77(3), 623-685.

Bodenstein, M. (2008). International asset markets and real exchange rate volatility. Review of Economic Dynamics, 11, 688-705.

Caporale, G. M., Amor, T. H., \& Rault, C. (2011). Sources of real exchange rate volatility and international financial integration: A dynamic generalized method of moments panel approach. Journal of International Development, http://dx.doi.org/10.1002/jid.1851

Cazzavillan, G., \& Donadelli, M. (2010). Understanding the Global Demand Collapse: Empirical Analysis and Optimal Policy Response. Ca' Foscari Working Paper N. 18/10

Christiano, L. J., \& Fitzgerald, T. J. (2003). The band pass filter. International Economic Review, 44, 435-465.

Please cite this article in press as: Donadelli, M., \& Paradiso, A. Does financial integration affect real exchange rate volatility and cross-country equity market returns correlation? North American Journal of Economics and Finance (2014), http://dx.doi.org/10.1016/j.najef.2014.03.001 
Colacito, R., \& Croce, M. (2010). The short- and long-run benefits of financial integration. American Economic Review, 100, $527-531$.

Colacito, R., \& Croce, M. (2013). International asset pricing with recursive preferences. Journal of Finance, 68(6), $2651-2686$.

Corden, W. M. (2002). Too sensational: On the choice of exchange rate regimes. Cambridge: MIT Press.

Corsetti, G., Dedola, L., \& Leduc, S. (2008). International risk sharing and the transmission of productivity shocks. Review of Economic Studies, 75, 443-473.

Corsetti, G., Dedola, L., \& Viani, F. (2012). The international risk sharing puzzle is at business cycle and lower frequency. Canadian Journal of Economics, 45(2), 448-471.

Courchene, T. J. (2003). FTA at 15, NAFTA at 10: A Canadian perspective on North American integration. The North American Journal of Economics and Finance, 14, 263-285.

Croce, M. (2008). Long-run productivity risk: A new hope for production-based asset pricing. UNC Working Paper.

Crucini, M. (1999). International and national dimensions of risk sharing. Review of Economics and Statistics, 81, 73-84.

Dellas, H., \& Hess, M. (2005). Financial development and stock returns: A cross-country analysis. Journal of International Money and Finance, 24(6), 891-912.

Devereux, M. B., \& Yetman, J. (2010). Leverage constraints and international transmission of shocks. Journal of Money, Credit and Banking, 42(6), 71-105.

Donadelli, M. (2013). Global integration and emerging stock market excess returns. Macroeconomics and Finance in Emerging Market Economies, 6(2), 1-36.

Donadelli, M., \& Persha, L. (2014). Understanding emerging market equity risk premia: Industries, governance and macroeconomic policy uncertainty. Research in International Business and Finance, 30, 284-309.

Epstein, L. G., \& Zin, S. E. (1989). Substitution, risk aversion, and the temporal behavior of consumption and asset returns: A theoretical framework. Econometrica, 57(4), 937-969.

Ferguson, I. F. (2011). United States-Canada trade and economic relationships: Prospects and challenges. Congressional Research Service Report for Congress.

Fitzgerald, D. (2012). Trade costs, asset market frictions, and risk sharing. American Economic Review, 102, $2700-2733$.

Goetzmann, W. N., Li, L., \& Rouwenhorst, K. G. (2005). Long-term global market correlations. Journal of Business, 78, 1-38.

Heathcote, J., \& Perri, F. (2002). Financial autarky and international business cycles. Journal of Monetary Economics, 49, 601-627.

Hufbauer, G. C. (2001). In G. C. Hufbauer (Ed.), North American convergence: An American perspective. Remarks at the annual policy conference of the Canadian association of business economists. Washington, DC: Peterson Institute for International Economics.

Jappelli, T., \& Pistaferri, L. (2011). Financial integration and consumption smoothing. The Economic Journal, 121, 678-706.

Johnson, R., \& Soenen, L. (2003). Economic integration and stock market co-movement in the Americas. Journal of Multinational Financial Management, 13, 85-100.

Kollmann, R. (2012). Limited asset market participation and the consumption-real exchange rate anomaly. Canadian Journal of Economics, 45(2), 566-584.

Lahrech, A., \& Sylwester, K. (2013). The impact of NAFTA on North American stock market linkages. The North American Journal of Economics and Finance, 25, 94-108.

Longin, F., \& Solnik, B. (1995). Is the correlation in international equity return constant: 1960-1990? Journal of International Money and Finance, 14, 3-26.

McCallum, J. (1995). National borders matter: Canada-U.S. regional trade patterns. American Economic Review, 85, 615-623.

Mandelman, F. S., Rabanal, P., Rubio-Ramìrez, J. F., \& Vilàn, D. (2011). Investment-specific technology shocks and international business cycles: An empirical assessment. Review of Economic Dynamics, 14(1), 136-155.

Mehra, R., \& Prescott, E. C. (1985). The equity premium: A puzzle. Journal of Monetary Economics, 15(2), 145-161.

Mehra, R., \& Prescott, E. C. (2008). In R. Mehra (Ed.), The handbook of the equity risk premium (pp. 1-36). Amsterdam: Elsevier.

Pancrazi, R. (2013). How beneficial was the great moderation after all? Warwick University Working Paper.

Poulson, B. W. (1990). North America: A case for economic integration. North American Review of Economics and Finance, 1(1), $1-8$.

Pukthuanthong, K., \& Roll, R. (2009). Global market integration: An alternative measure and its application. Journal of Financial Economics, 92(2), 214-232.

Ready, R., Roussanov, N., \& Wards, C. (2013). Commodity trade and the carry trade: A tale of two countries. The Wharton School Working Paper.

Reinhart, C. M., \& Todd Smith, R. (2001). Temporary controls on capital inflows. NBER Working Papers N. 8422.

Restoy, F., \& Weil, P. (2011). Approximate equilibrium asset prices. Review of Finance, 15, 1-28.

Rugman, A. (2000). The end of globalization. London: Random House Business Books.

Santos Monteiro, P. (2008). Testing full consumption insurance in the frequency domain. Warwick University Working Paper.

Suzuki, Y. (2014). Financial integration and consumption risk sharing and smoothing. International Review of Economics and Finance, 29, 585-598.

Tavares, J. (2009). Economic integration and the co-movement of stock returns. Economics Letters, 103, 65-67.

Tretvoll, H. (2008). Home-bias in consumption and equities: can trade costs jointly explain both? New York University Working Paper. Weil, P. (1989). The equity premium puzzle and the risk-free rate puzzle. Journal of Monetary Economics, 24, 401-422. 